\title{
AHP METHODOLOGY APPLICATION IN GARAGE-PARKING FACILITY LOCATION SELECTION
}

\begin{abstract}
The paper deals with the selection of traffic infrastructure facility location by applying the AHP (Analytic Hierarchy Process) multi-criteria analysis methodology. The proposed methodology is applied in a case study to solve the problem of selecting a location for the garage-parking facility in the town of defined characteristics. The paper analyses the characteristics of five potential locations (alternatives), the selection of criteria and measures for assessing the alternatives and presents the input data preparation, the application of the selected method and the analysis results. All the relevant criteria for the analyses were included: the traffic, the economic criteria and those which nowadays are of great significance: the influence of the facility on the environment and the social criteria which is in accordance with the sustainable development principles. The goal of the paper is to present the procedure of the AHP method application on the complex issue of traffic planning and to confirm the adequacy of the chosen method on the traffic facility strategic planning.
\end{abstract}

\section{KEY WORDS}

location selection, infrastructure facilities, garage-parking facility, multi-criteria analysis, optimization

\section{INTRODUCTION}

Planning of traffic infrastructure facilities starts by recognizing the traffic problem and is followed by defining the problem (the goals, the criteria and measures for assessment of the goals fulfilment, limitations, etc.) and generating possible alternative solutions. In order to ensure the best, that is, the optimal solution of the problem, all alternatives must be analyzed and the one selected which best fulfils all the set goals and has the most favourable traffic and economic principles as well as principles in accordance with the sustainable development, social and environmental effects [1]. This determines the need for many different measuring criteria, both the quantitative and the qualitative ones, to be used in the optimization process and makes the optimization process complex.

For solving such tasks numerous methods have been developed which are classified as multi-criteria analysis methods, that is, multi-criteria optimization methods (e.g., PROMETHEE - Preference Ranking Organisation METHod for Enrichment Evaluations, ELECTRE - Elimination and (Et) Choice Translating Reality, AHP - Analytic Hierarchy Process and other) [2, 3, 4, 5]. Multi-criteria methods are used as support in strategic planning in general $[6,7]$ and when selecting the locations for different facilities (hospitals, hotels, waste management centres, warehouses, wind farms, fire station etc.) $[8,9,10,11,12,13]$.

Described in simple words, the construction of a traffic facility starts at the strategic level by defining the location of the facility and ends with the implementation of the designed solution. In between, if the process is well led, there is a complex decision making process that includes participation of different disciplines in order to assure that, as was mentioned before, all necessary demands are met. The growth of urbanisation and environmental problems that goes with it has made the process even more demanding and new methods that can optimise solutions by taking into consideration different criteria are developed and used in different segments of traffic planning and design. As the AHP method has proven to be adequate for selecting the medical and tourist facility locations [8, 9, 10], this paper analyses the possibility of applying the AHP method on strategic planning of traffic infrastructure facilities. The intention is to prove that by applying the multi-criteria analysis procedures, that is, the selected AHP method, the traffic problem can be considered under all given conditions in an integral way and the best solution for solving the defined traffic problem at the strategic level can be selected. The main goal of this paper is clear: to present the procedure of the AHP method applica- 
tion on traffic planning problems and to confirm the adequacy of the chosen method on the traffic facility strategic planning level for selecting the most favourable location for the traffic facility. As the case study for the traffic facility location selection the complexity of one segment of traffic planning is presented, this being the selection of the most favourable garage-parking facility (GPF) location in town.

\section{AHP METHOD}

There are numerous methods of multi-criteria analysis [3, 4, 5, 14, 15], most of which have also been applied in certain aspects of traffic planning [16, 17]. This paper analyses the possibilities of applying the pair-wise comparison methods, one of which is the AHP method, for garage-parking facility location selection.

AHP is a priority method applicable to problems that can be represented by a hierarchical structure $[18,19,20]$. The top of the hierarchy is the goal, one level lower are criteria and there is the possibility of having more levels for sub-criteria. The lowest level is represented by alternatives. AHP method is based on estimating relative priorities (weights) of criteria and alternatives on which pair-wise comparison matrix for criteria and pair-wise comparison matrices for alternatives (one matrix for each criterion) are generated. These matrices are formed by pair-wise comparison of alternatives regarding their importance with respect to each criterion and pair-wise comparison of criteria with respect to the goal using a pair-wise comparison scale shown in Table 1.

The columns in matrices are normalized in order to calculate the priority vector for the criteria and the priority vectors for alternatives regarding each criterion. As a result, the overall priority matrix of the alternatives is formed in which columns are priority vectors of alternatives for each criterion. Multiplying this matrix with the priority vector of criteria the overall priority vector of alternatives is calculated. The overall priority vector defines the priority (weight) of each alternative in respect to the goal so the ranking of alternatives can be made.

The advantage of this multi-criteria method is that it can be used when just the pair-wise comparison of alternatives according to each criterion and the pair-wise comparison of criteria towards the goal are known. Therefore, this method enables the ranking of alternatives which are not exactly valued under each criterion separately, that is, if the importance of every single criterion is not exactly defined.

In this case, the consistency of pair-wise comparison matrices of alternatives, criteria and also of overall priority matrix is analysed by calculating the inconsistency index. The inconsistency index should be lower than 0.1. In that case the judgments are consistent. If the inconsistency index is higher, then the re-evaluation of pair-wise comparison of alternatives and criteria is required.

For ranking the alternatives using the multi-criteria method AHP the next steps have to be performed:

1. Define the problem (the goal, the criteria, the alternatives);

2. Define the hierarchy;

3. Perform pair-wise comparison of alternatives in respect to each criterion;

4. Perform pair-wise comparison of criteria in respect to the goal;

5. Apply the AHP method to estimate the overall priority vector of alternatives in respect to the goal;

6. Form the rank-list of alternatives;

7. Perform the sensitivity analysis;

8. Make the final decision.

The characteristics of AHP method enable its application on a wide range of problems. However, its application is specially stressed if it is applied on different levels of strategic or tactical traffic planning where often there are no precisely quantified data (which is, as a rule, the case in operational planning). Unlike the usual multi-criteria assessment of every alternative regarding each criterion separately, the possibility of pair-wise comparison of alternatives in relation to a specific criterion, which is enabled by the AHP method, significantly simplifies, that is, facilitates the strategic planning.

The application of the stated method on traffic planning problems has been analyzed in different papers: when selecting the type of the garage-parking facility [21], when selecting the type of transportation system [22], etc. The possibility of its application on traffic planning has been considered in general in numerous papers [2, 23, 24]. In this paper, the stated methodology will be examined on selecting the garage-parking

Table 1 - The AHP pair-wise comparison scale (source: [18])

\begin{tabular}{||c|l||}
\hline Intensity of weight, importance, preference & \multicolumn{1}{|c||}{ Definition } \\
\hline \hline 1 & Equal importance (no preference) \\
\hline 3 & Moderate importance (moderate preference) \\
\hline 5 & Strong importance (strong preference) \\
\hline 7 & Very strong importance (very strong preference) \\
\hline 9 & Extreme importance (extreme preference) \\
\hline $2,4,6,8$ & Intermediate values \\
\hline
\end{tabular}


facility location by using EXPERT CHOICE 11.5 software which has been developed based on the theoretical and mathematical principles of the AHP method [25].

\section{AHP METHODOLOGY APPLICATION IN GARAGE-PARKING FACILITY LOCATION SELECTION}

The possibility of applying the AHP method in the process of traffic planning is examined in the casestudy of a town situated on the Adriatic coast. The town is of a typical European urban development type with the old historic centre inadequate for motorized traffic and has typical traffic problems such as too many cars, an inappropriate road network and lack of parking places.

Urban development characteristics of the historical part as well as the natural ones are taken into consideration when analysing the alternative locations for the GPF. The multi-criteria optimization with AHP procedure is applied in order to rank the GPF locations and the priority of GPF construction can be determined.

\subsection{Alternative locations}

When selecting the location for constructing a garage-parking facility, the priority task is to resolve the location of vehicles at standstill which enables the extension of a high-quality traffic solution for a certain narrower or broader zone around the facility in question because it also enables the location of vehicles outside the street area [26]. Another significant traffic component of locating the GPF is the analysis of traffic load influence which such facility generates within the traffic network. The analysis is conducted by checking the level of service of intersections through which the facility is filled up and emptied. It follows from the above that the strategies of resolving the parking problems in cities differ one from another and that the following development scenarios are possible:

1. construction of larger garage-parking facilities in the broader zone of the city centre: this solution is favourable for the users (in relation to the accessibility of the facility on foot), but it influences the street network traffic load in the city centre in the most unfavourable way;

2. construction of larger garage-parking facilities outside the city centre zone (in outlying districts) providing the appropriate traffic connections between the facility and the city centre (e.g., by introducing public transport service) with smaller, exclusive garage-parking facilities in the city centre.

After adopting the general strategy for GPF planning, the location must be determined which, besides the stated traffic conditions, must meet a range of oth- er interdisciplinary criteria. The possible criteria for GPF location selection could be classified into a few categories: the traffic-related criteria (vicinity of pedestrian destinations, correlation to public transport), urban development criteria (blending in the surroundings, social aspects), economic criteria and construction criteria (construction adequacy of the location and other).

Thus, as a case-study, this paper analyses the GPF location selection in the city on the Adriatic coast which is the administrative centre of a micro-region (ca. 30,000 inhabitants) and whose main business and administrative facilities are situated in the historical city centre.

At the strategic planning level, five alternative locations were analysed, two of which (alternative $A$ and alternative B) allocated in the very centre of the town (first scenario) and three outside the centre (alternatives C, D and E) (second scenario). Standard garage-parking facilities with semi-circular ramps and approximately $2,600 \mathrm{~m}^{2}$ of plan area were adopted for analyses. For different locations, depending on the location parameters, different numbers of storeys were planned. The characteristics of the selected location and the GPF are shown in Table 2.

\subsection{Criteria}

The usual criteria applied in a strategic location selection of a traffic facility $[1,26]$ were used as comparison criteria: traffic criteria (T); economic criteria (E); environmental criteria (EN) and social criteria (S).

As a part of economic criteria soil characteristics at defined locations were elaborated because these criteria are recognised as important in today's urban planning theory [27].

Due to the urban development characteristics of the historical part as well as the natural characteristics, primarily the construction in the coastal zone and the karst properties of the ground, specific problems in resolving the traffic issues have been occurring (transportation facilities of unfavourable geometrical characteristics, densely built environment, significant oscillation of average day traffic volumes - ADTV during the year and other) together with specific geotechnical issues (part of the terrain is situated on the levelled part of the sea bottom, karst terrain with different thickness of clay layer, impact on ground waters, etc.).

Taking into consideration the stated specific characteristics of the analysed issue and the availability of data required for analysing the possibility of AHP methodology application for solving this kind of issues, the selected criteria contain sub-criteria which guarantee a comprehensive assessment and comparison of the proposed locations. As already stated, a standard garage-parking facility with semicircular ramps, $2,600 \mathrm{~m}^{2}$ of plan area but different number of storeys, depend- 
ing on the location parameters, was analysed on all locations. In order to make a comparison of GPF shape alternatives on the specific and selected location additional traffic and other criteria should be introduced which would relate to the very facility, e.g., the degree of utilization of the facility surface, lengths of movement within the facility and other which was analysed in [26]. However, these criteria do not have influence at the planning level which is analysed in this example.

\section{$T$ - Traffic criteria}

The function of garage-parking facilities is to house vehicles in standstill and reduce the number of additional rides which are the result of parking place search. The concentration of a certain amount of vehicles within a zone creates an additional street network traffic load, especially on the intersections which are the vehicle entry points. When assessing the facility locations, this aspect must be examined in advance. The users of the GPF continue their journey after parking their vehicles in the facility on foot, so, when as- sessing the location, the pedestrian accessibility of potentially interesting city destinations must also be taken into consideration.

Three main traffic criteria and several sub-criteria were defined for conducting the multi-criteria analysis.

They respect the following parameters:

T1 - capacity of the planned GPF (number of parking places),

T2 - traffic load of the existing road network, T21 - capacity of entries/exits of the GPF,

T22 - capacity of the surrounding intersections (level of service),

T3 - traffic importance and accessibility in relation to the existing transportation network,

T31 - pedestrian accessibility, vicinity of interesting destinations which can be reached on foot,

T32 - accessibility to the primary and roadway network (length of approach, potential barriers).

Table 2 - Characteristics of selected location and GPF

\begin{tabular}{|c|c|c|c|c|}
\hline \multirow{2}{*}{$\begin{array}{c}\text { Alter- } \\
\text { natives }\end{array}$} & \multicolumn{2}{|c|}{ Location characteristics } & \multirow{2}{*}{$\begin{array}{l}\text { Main characteris- } \\
\text { tics of the facility }\end{array}$} & \multirow{2}{*}{$\begin{array}{l}\text { Estimation of possi- } \\
\text { bilities for commer- } \\
\text { cial use of the facility }\end{array}$} \\
\hline & $\begin{array}{l}\text { Space and traffic position, per- } \\
\text { centage of lot development }\end{array}$ & $\begin{array}{l}\text { Geotechnical properties of soil, type } \\
\text { of excavation and pit propping }\end{array}$ & & \\
\hline$A$ & $\begin{array}{l}\text { - city centre (historical part) } \\
\text { - assured pedestrian accessibil- } \\
\text { ity to destinations of interest } \\
\text { - poor connection with } \\
\text { roadway network } \\
\text { - built-up area }\end{array}$ & $\begin{array}{l}\text { - excavation approximately } 17,800 \mathrm{~m}^{3} \text { : } \\
70 \% \text { in soil with fragments, } 30 \% \\
\text { in karstified carbonate rock } \\
\text { - garage facility foundations are } \\
\text { above underground water level }\end{array}$ & $\begin{array}{l}200 \text { parking places } \\
1 \text { underground } \\
\text { and } 1 \text { semi- } \\
\text { embedded storey }\end{array}$ & $\begin{array}{l}\text { Possibility for } \\
\text { commercial use of } \\
\text { garage all year long }\end{array}$ \\
\hline B & $\begin{array}{l}\text { - city centre } \\
\text { - } \text { assured pedestrian accessibil- } \\
\text { ity to destinations of interest } \\
\text { - poor connection to roadway network } \\
\text { - built-up area }\end{array}$ & $\begin{array}{l}\text { - excavation approximately } 18,600 \mathrm{~m}^{3} \text { : } \\
75 \% \text { in soil with fragments } 25 \% \\
\text { in karstified carbonate rock } \\
\text { - } 2 \text { underground garage levels are } \\
\text { below underground water level } \\
\text { - excavated pit propping will } \\
\text { be particularly complex }\end{array}$ & $\begin{array}{l}500 \text { parking places } \\
2 \text { underground lev- } \\
\text { els and } 4 \text { storeys } \\
\text { above ground level }\end{array}$ & $\begin{array}{l}\text { Possibility for } \\
\text { commercial use of } \\
\text { garage all year long }\end{array}$ \\
\hline C & $\begin{array}{l}\text { - } \text { outside city centre } \\
\text { - } \text { destinations of interest out } \\
\text { of pedestrian accessibility } \\
\text { - good connection to city ring- } \\
\text { road and roadway network } \\
\text { - } \text { area is partly built-up }\end{array}$ & $\begin{array}{l}\text { - excavation approximately } 15,800 \mathrm{~m}^{3} \text { : } \\
80 \% \text { in soil with fragments, } 20 \% \\
\text { in karstified carbonate rock } \\
\text { - one underground garage level is } \\
\text { below underground water level } \\
\text { - excavated pit propping will be } \\
\text { particularly complex, karstified } \\
\text { bedrock is deeply settled for } 70 \% \\
\text { of foundation (up to } 15 \text { meters) }\end{array}$ & $\begin{array}{l}500 \text { parking places } \\
1 \text { underground } \\
\text { level and } 5 \text { storeys } \\
\text { above ground level }\end{array}$ & $\begin{array}{l}\text { Not suitable for } \\
\text { commercial use } \\
\text { off season }\end{array}$ \\
\hline$D$ & $\begin{array}{l}\text { - suburban part of the city, } \\
\text { close to sports' facilities } \\
\text { - } \text { necessary to implement public trans- } \\
\text { port for the connection to the centre } \\
\text { - good connection to roadway network } \\
\text { - } \text { area partly built-up }\end{array}$ & $\begin{array}{l}\text { - excavation approximately } \\
15,700 \mathrm{~m}^{3}: 100 \% \text { in soil } \\
\text { - garage facility foundations are } \\
\text { above underground water level } \\
\text { - excavated pit propping will } \\
\text { be complex, karstified bed- } \\
\text { rock is deeply settled }\end{array}$ & $\begin{array}{l}500 \text { parking places } \\
1 \text { underground } \\
\text { level and } 5 \text { storeys } \\
\text { above ground level }\end{array}$ & $\begin{array}{l}\text { Not suitable for } \\
\text { commercial use } \\
\text { off season }\end{array}$ \\
\hline$E$ & $\begin{array}{l}\text { - suburban part of the city } \\
\text { - introduction of public transport } \\
\text { lines to the centre required } \\
\text { - good connection to lo- } \\
\text { cal roadway network } \\
\text { - partly built-up area }\end{array}$ & $\begin{array}{l}\text { - excavation for foundation approxi- } \\
\text { mately } 3,100 \mathrm{~m}^{3}: 100 \% \text { in soil } \\
\text { - foundations are above level } \\
\text { of underground water }\end{array}$ & $\begin{array}{l}300 \text { parking places } \\
3 \text { storeys above } \\
\text { ground level }\end{array}$ & $\begin{array}{l}\text { Not suitable for } \\
\text { commercial use } \\
\text { off season }\end{array}$ \\
\hline
\end{tabular}




\section{E - Economic criteria}

The foreseen economic criteria take into consideration the cost of facility construction as well as the costs resulting from exploitation (facility maintenance) and the profit which can be made by exploitation.

The cost of facility construction is significantly influenced by the amount and complexity of the facility foundation engineering, that is, the geotechnical and hydrotechnical conditions on the location. The amount of excavation takes into account excavation for foundations and underground level/s. The conceptual design of the garage facilities was adjusted to the field conditions in terms of their vertical positioning. That resulted in different depths and types of foundation structure and in different number of underground and semi-embedded storeys, explained in Table 2. The quantities of excavation material, the complexity of facility foundation engineering and other related details for the selected locations are calculated and defined on the basis of [28]. Therefore, the following criteria and sub-criteria were taken into consideration when analysing the locations in this paper:

\section{E1 - construction costs,}

E11 - geotechnical characteristics of the terrain and foundation engineering method, type of soil and rocks on the location, hydro-technical characteristics of the terrain (water permeability and ground water level), size of the excavation (depends on the size of the facility and the number of underground storeys), the necessity of foundation pit protection due to possible side caving and inrush of ground water as well as the foundation engineering method;

E12 - necessary removal of the existing structures from the location,

E13 - facility construction cost, estimated in relative terms in relation to other facilities taking into consideration the size of the facility and the number of underground storeys,

E2 - profitability of the facility - possible profit from charging the parking in the facility was assessed by taking into consideration the size of the facility (number of parking spaces) and the location (vicinity of the centre was considered as a positive effect because it assures commercial use during the entire year).

The calculation of facility costs usually comprises the costs of construction, maintenance and removal of the facility. Costs of maintenance and removal of the GPF after exploitation were not assessed in this case because no further typization of the structure was made. It must be mentioned that possible costs of traffic system adjustment or any adjustment outside the parking facility were not taken into consideration (e.g. implementation of public transport etc.).

\section{EN - Environmental criteria}

The legislative regulations of the Republic of Croatia $[29,30]$ regulate the implementation of procedures for assessing the impact of the construction on the environment. The parking facilities from the stated documents are mentioned in the "Regulation on projects assessed on the necessity of estimating the impact of the project on the environment" in case of planning the parking lots as self-sufficient projects whose area is 2 ha or more. The analysed GPFs have a plan area of $2,600 \mathrm{~m}^{2}$. Regardless of a non-existing legislative regulation for case-study elaboration about the impact on the environment and assessment of the impact on the environment of the parking facilities covering less than $2 \mathrm{ha}$, when selecting the location for any GPF, the environmental criteria should be taken into consideration.

In the category of environmental criteria special attention was paid to the influence the construction of a garage facility has on the environment of specific locations, taking into consideration the sensitivity of geotechnical conditions and other negative effects on the soil, the air and the water which occur during the construction [31, 32]. The influence of the facility under construction was analysed as well as the aesthetic criteria of influencing the urban view of a particular location after the construction has been completed. The selected environmental criteria were the following:

EN1 - influence on the environment during the construction,

EN11- influence of the GPF construction on water resources implies the possible harmful influence both on the ground waters and on the sea which is nearby. The terrains with karst hydrological and geological characteristics which prevail on the Croatian coast of the Adriatic are strongly characterised by water permeability of the terrain and the transmissivity. The analysed locations are situated outside the sanitary protection and drinking water source zones, which could otherwise present the most significant danger. However, during the construction, the pollution can be transferred by underground waters to the nearby sea. By constructing relatively larger facilities on the proposed locations a backfilling of the natural drainage canals can occur and sudden flooding hazard can be increased. 
EN12- harmful influence of GPF construction on the soil: the amount and kind of material (residue from previous construction, engineering soil or rock) are different on every location. The excavated material must be transported to adequate disposal sites of construction debris. However, if treated adequately, the excavated rock material can be used as industrial stone for different purposes. Therefore, this kind of base is more favourable from the environmental protection point of view.

EN13- harmful influence of GPF construction on the air quality and the increased level of noise: during construction, an increased level of noise and a larger concentration of dust can be expected due to blasting and construction machinery operation. The same can be expected when transporting the construction material from the construction site to adequate disposal sites.

EN2- influence on the environment during facility exploitation was analysed in relation to the GPF size and location (it is assumed that a larger number of parking places and the location closer to the centre generates e.g., traffic jams which are partially the result of the GPF).

EN3- relates to the assessment of influence that the facility has on the existing (and planned)

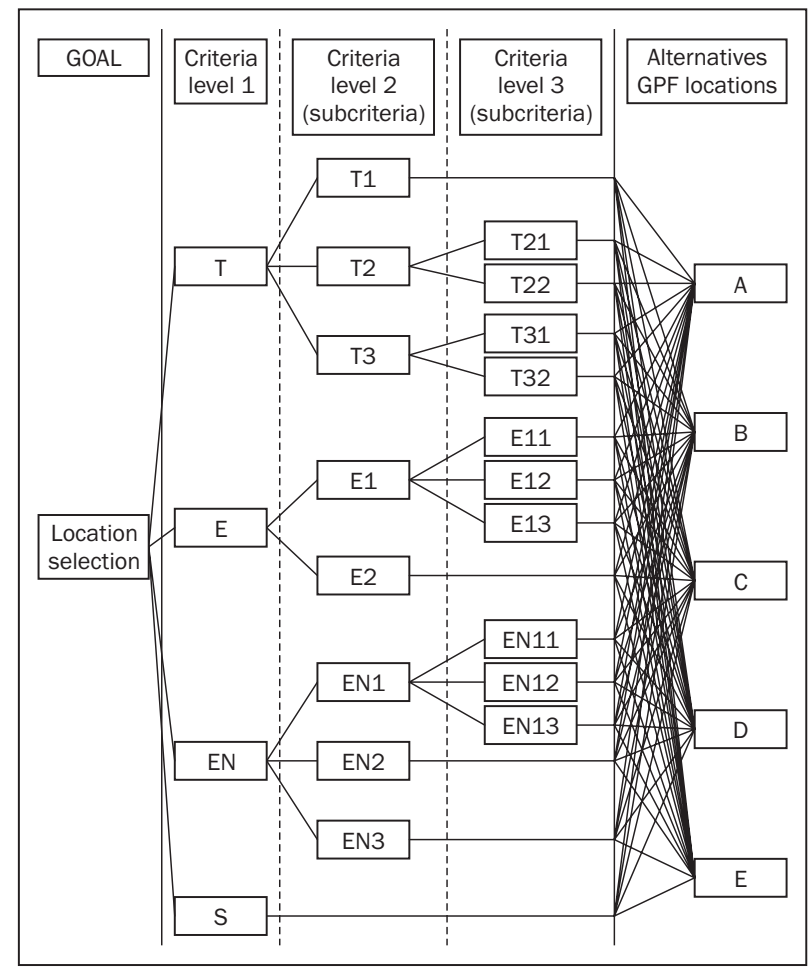

Figure 1 - Hierarchy structure city view which was assessed in relation to the number of storeys of the facility and its location within the specific zone (historical centre of the city or outskirts).

\section{S - Social criterion}

The social criterion is usually assessed through the number of people who would benefit from a certain project. In this case, the facilities housing a larger number of vehicles and the facilities which the local inhabitants would benefit from during the entire year (e.g., the facilities situated near the city centre or sports facilities) were favoured. Possible negative effects for the society were taken into consideration through other criteria (e.g. traffic volume increase in traffic criteria) so they were not discussed as negative social effects.

The hierarchy of the garage-parking facility location selection is shown in Figure 1.

\subsection{Pair-Wise Comparison of Alternatives}

The AHP method application presumes pair-wise comparison of all alternatives with respect to each defined criterion (or sub-criterion) of the above hierarchy. The comparison can be conducted based on the measurable or estimated importance/preference of one alternative in relation to the other. The alternatives assessment accuracy according to a specific criterion significantly influences the consistency and the quality of the pair-wise comparison of alternatives.

Based on all the defined criteria a pair-wise comparison of all alternatives was conducted according to every determined criterion (Table 3). The values in Table 3 are preferences of alternatives written in rows in relation to the alternatives written in columns with respect to a specific criterion. The preference value written without brackets defines the alternative in that row to be better than the alternative in that column with respect to the criterion. If the alternative preference is written in brackets, then the alternative in that row is worse than the alternative in the column. For example, in relation to traffic criterion $\mathrm{T} 1$, alternative $\mathrm{A}$ is significantly worse than alternative $B$ (value 7 ) while alternative $B$ equals alternatives $C$ and $D$ (value 1 ) and alternative $C$ is significantly better than alternative $\mathrm{E}$ (value 5).

The consistency of alternative pair-wise comparison matrices must be examined according to each criterion by applying the inconsistency index. The same also goes for defining the sub-criteria pair-wise comparison matrices in relation to criteria and criteria pair-wise comparison matrix in relation to the goal. Eventually, the overall inconsistency is examined. If the inconsistency index is larger than 0.1, the estimated alternatives, sub-criteria and criteria preferences must be analysed and corrected in order to reduce the value. 
Table 3 - Pair-wise comparison of alternatives in relation to each criterion

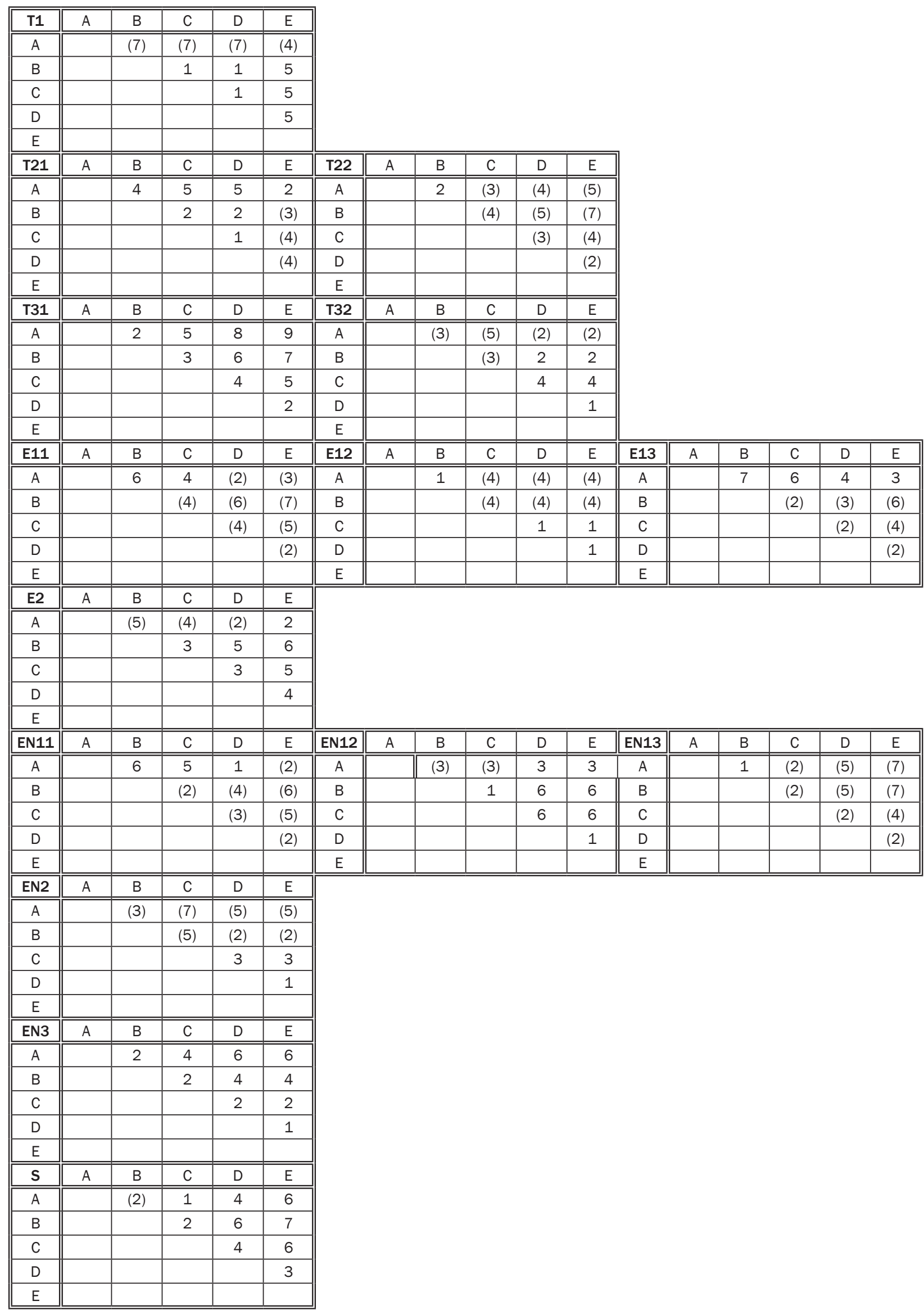




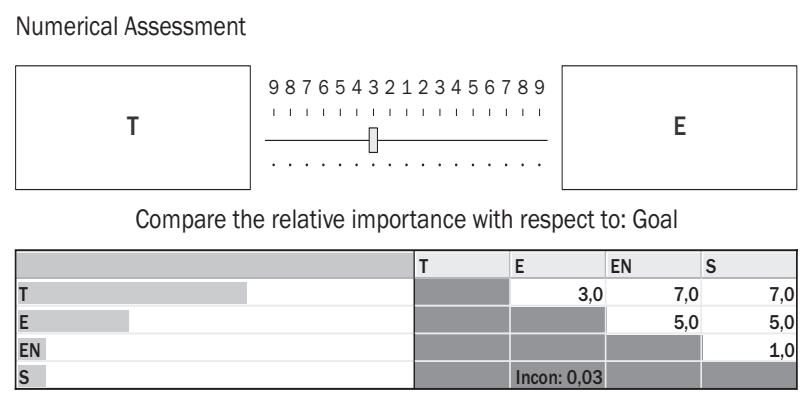

Numerical Assessment

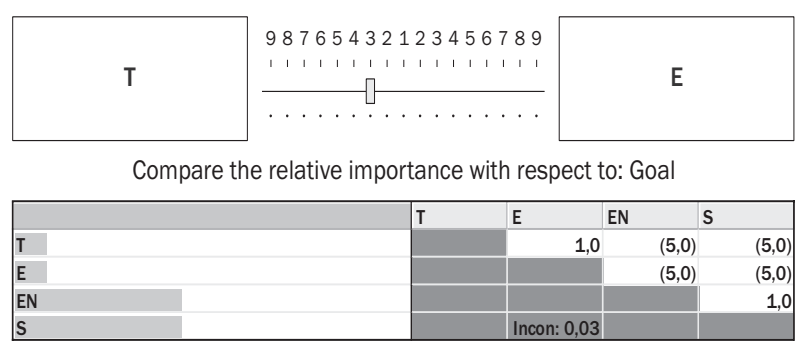

Figure 2 - Pair-wise comparison of criteria in relation to the goal for scenario A (left) and B (right)

In the analysed case the inconsistency index of all alternatives pair-wise comparison matrices is adequate (that is, the inconsistency index is less than 0.06).

\subsection{Criteria importance determination}

The criteria and sub-criteria importance determination is a very important step in the optimal solution selection procedure. When selecting the traffic facility location, the most important criteria are usually the traffic and the economic criteria. The specific requirements of a certain environment (in this case, the tourist centre located in the sensitive karst area) can impose, however, the environmental and the social criteria as the very important ones. The criteria importance in selecting the most favourable solution depends also on a specific requirement connected with the development strategy of a certain area.

In order to examine the method sensitivity in relation to changes of the criteria importance, two approaches were analysed in this paper (the rank-list of criteria according to importance: 1 . the most important criterion, 2. the less important criterion, etc.):

- criteria importance according to scenario A:

1. traffic criterion,

2. economic criterion,

3. environmental and social criteria;

- criteria importance according to scenario B:

1. environmental and social criteria,

2. traffic and economic criteria.

By applying the importance values from Table 1 a pair-wise comparison of criteria in relation to the goal was made. Figure 2 (left part) shows for scenario A that the traffic criterion $\mathrm{T}$ is moderately more important (value 3) than the economic criterion. The environmental and the social criteria are of equal importance (value 1) and less important than the economic criterion (value 5) and the traffic criterion (value 7). For scenario B in Figure 2 (right part) the environmental and the social criteria are of same importance (value 1) and both are strongly more important (value 5) in relation to the traffic and the economic criteria.

Tables in Figure 2 show that the inconsistency index for scenario $A$ is 0.03 and for scenario B 0.0. Therefore the criteria comparison consistency is also adequate. It must be, however, noted that all the subcriteria were assumed to be equal in relation to the criteria in order to enable the simplification of the presentation.

\subsection{Results of AHP method application}

\subsubsection{Scenario A}

Alternatives analysis conducted by AHP method application according to scenario A, shown in Figure 3, singles out alternative $B$ as the optimal one and with a very similar overall priority vector value alternative $C$ (value difference is 0.002). Other alternatives (D, A, E) have a significantly smaller overall priority vector. The overall inconsistency index is adequate because it is 0.02 .

The performance sensitivity graph analysis points to a significant ranging of the alternative $B$ priority vector (Figure 4, left part). Therefore, this alternative is a very favourable one from the social and economic point of view, but unfavourable from the environmental point of view. Alternative $C$ displays a constancy in priority vector values which, along with the very slight difference in the overall priority vector value, indicates

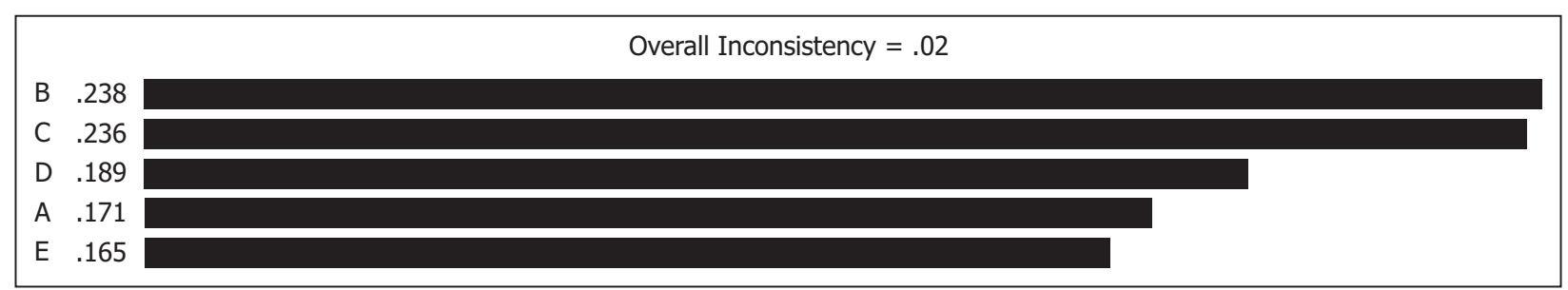

Figure 3 - Result of multi-criteria GPF locations ranking by applying the AHP method for scenario A 

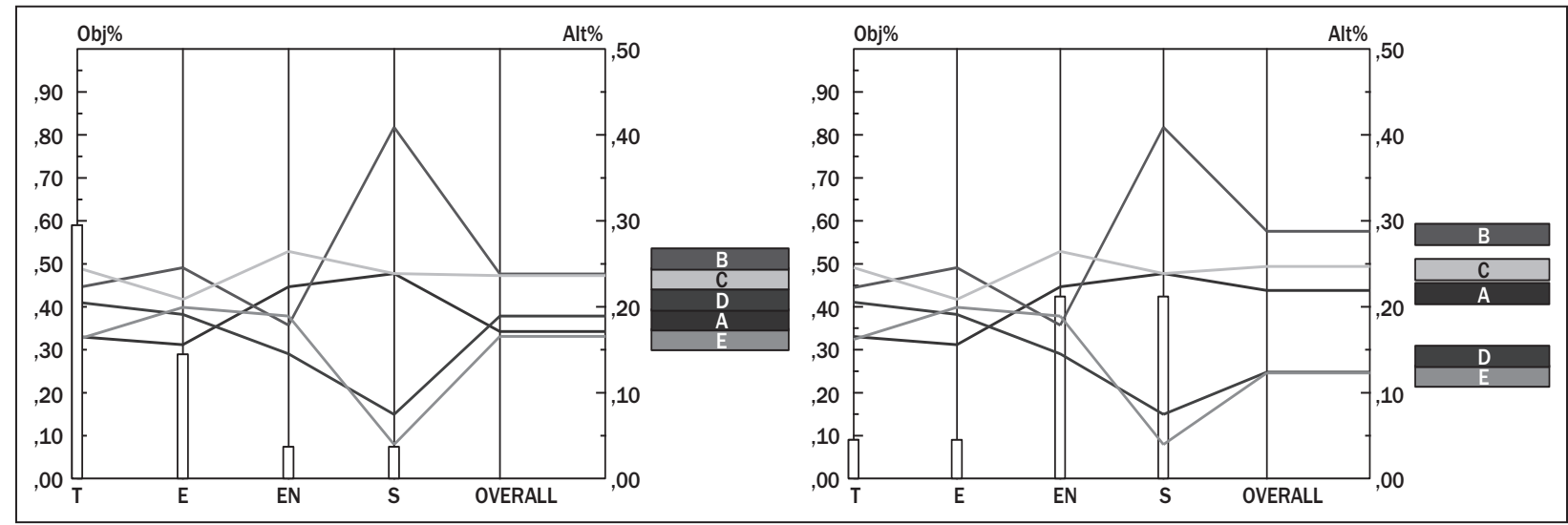

Figure 4 - Performance sensitivity graph for scenario A (left) and B (right)

that it can be adopted as the optimal one. This means that, besides the overall priority vector value for alternatives in respect to the goal, the priority vector values according to particular criteria is a significant data generated through the AHP procedure because it enables detailed analysis of advantages of every single alternative.

\subsubsection{Scenario B}

Alternatives analysis conducted by AHP method application according to scenario $B$, shown in Figure 5 , singles out alternative $B$ as the optimal one (0.288). It is followed by alternatives $C(0.247)$ and $A$ (0.219). Other analysed alternatives ( $D$ and $E$ ) have a significantly smaller overall priority vector value which indicates that they should either not be taken into further consideration or, if the execution dynamics is being determined, that they are ranked low on the priority list.

The overall inconsistency index is adequate because it is 0.01 .

If also priority vector values for every alternative are compared, as in the previous example using the performance sensitivity graph (Figure 4, right part), what is immediately noted is a pronounced preference of alternative $B$ in one of the criteria (the social one) and a relative preference in one of the other criteria (the economic one). In this case alternative $\mathrm{C}$ also has similar priority vector values according to all criteria, out of which the economic criterion vector value is somewhat worse. According to scenario $\mathrm{B}$, significantly worse are alternatives $\mathrm{D}$ and $\mathrm{E}$.

\subsubsection{Final decision}

Based on the conducted analysis according to scenarios $\mathrm{A}$ and $\mathrm{B}$ of criteria importance, the best GPF location is alternative $B$ which is followed by alternative C. Alternatives A, E and D are ranked as the $3^{\text {rd }}$, the $4^{\text {th }}$ and the $5^{\text {th }}$ in both scenarios.

Since alternative $B$ is less favourable than alternative $\mathrm{C}$ according to the environmental criterion, either alternative $\mathrm{C}$ can be selected from the graphical presentation of sensitivity analysis as the final one or the social criterion can be elaborated in more detail and the ranking should be repeated. The results can also be used to define the order of construction of the proposed garage facilities because they show the need for different GPF from different perspectives.

\section{CONCLUSION}

The complexity of traffic planning and design imposes the need of finding new methods and tools for process optimisation. Most of the multi-criteria methods can be applied when assessing the traffic projects if the alternatives are assessed exactly according to all criteria. However, the advantage of the AHP method is that it can be applied when there are only pair-wise comparisons of the alternatives with respect to criteria and pair-wise comparisons of criteria with respect to goal at disposal which can be very useful for the strategic planning level (when there are no detailed elaborations of the project). In between there can be several levels of hierarchy (sub-criteria).

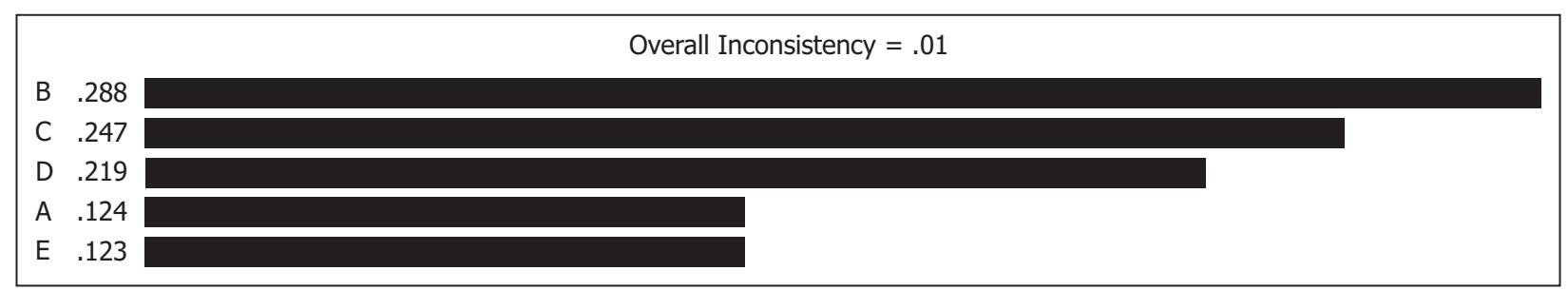

Figure 5 - Result of multi-criteria GPF location ranking by applying the AHP method for scenario B 
The application of the AHP method for the selection of a traffic facility optimal location enables interactive alternative locations comparison based on different criteria (and sub-criteria), defining the criteria importance in respect to the goal (and sub-criteria with respect to the criteria), evaluation of alternatives priorities with respect to each criterion and finally to the goal and the sensitivity analysis of the results.

Based on the analysed case study of AHP method application it can be concluded that this method discriminates precisely the specific alternatives taking into consideration the integrity of the set criteria which, in turn, ensures a clear determination of alternatives priorities to form the rank-list when selecting a garage-parking facility location or facility construction priority. By elaborating a larger number of criteria, the advantages of this method would be by all means even more prominent. Therefore, a detailed elaboration of a larger number of criteria can be suggested for a specific application whose goal is to ensure the maximum objectivity and quality level of alternatives selection. After the location selection in this case study, an analysis of AHP application in relation to other multi-criteria analysis methods should be conducted during the second transportation facility planning stage - the typization of the facility itself.

Based on the analysed case study of AHP method application it can be confirmed that the AHP method is adequate to be used on traffic facility strategic planning level for traffic facility location selection.

\section{Dr. SC. ALEKSANDRA DELUKA-TIBLJAŠ \\ E-mail: deluka@gradri.hr \\ Dr. Sc. BARBARA KARLEUŠA \\ E-mail: barbara.karleusa@gradri.hr \\ Dr. sc. ČEDOMIR BENAC \\ E-mail: cedomir.benac@gradri.hr \\ Sveučilište u Rljeci, Građevinski fakultet \\ V.C. Emina 5, 51000 Rijeka, Hrvatska}

\section{SAŽETAK}

\section{IZBOR LOKACIJE GARAŽNO-PARKIRNOG OBJEKTA AHP METODOM}

U radu je prikazana metodologija izbora lokacije prometnog infrastrukturnog objekta primjenom metode višekriterijske analize AHP (Analytic Hierarchy Process). Predložena metodologija je primijenjena na primjeru (case study) odabira lokacije garažno-parkirnog objekta (GPO) u gradu definiranih obilježja. U radu su analizirane karakteristike definiranih potencijalnih lokacija objekata, definirani kriteriji i mjere za vrednovanje varijanata, prikazana priprema ulaznih podataka, primjena izabrane metode $i$ rezultati analize. Kroz odabir kriterija nastojalo se obuhvatiti sve relevantne kriterije: prometne, ekonomske i danas vrlo važne kriterije: utjecaj objekata na okoliš i socijalni kriteriji. Cilj rada je prikazati metodologiju provođenja izbora AHP metodom te dokazati primjerenost izabrane metode na razini složenog procesa strateškog planiranja prometnih ob- jekata na primjeru odabira lokacije garažno-parkirnog objekta.

\section{KLJUČNE RIJEČI}

izbor lokacije, infrastrukturni objekti, garažno-parkirni objekt, višekriterijska analiza, optimizacija

\section{LITERATURE}

[1] Pas, E.I.: The urban transportation planning process: The geography of urban planning, Gilford Press, New York, 1995, pp. 53-77

[2] Karleuša, B., Deluka-Tibljaš, A., Benigar, M.: Mogućnosti primjene postupaka višekriterijske optimizacije u prometnom planiranju i projektiranju, Suvremeni promet, Vol. 23, No. 1-2, 2003, pp. 104-107

[3] Opricović, S.: Višekriterijumska optimizacija, Naučna knjiga, Beograd, 1986

[4] Triantaphyllou, E.: Multi-criteria decision making methods: A comparative study, Kluwer Academic Publishers, Nederalands, 2000

[5] Multiple Criteria Decision Analysis: State of the Art Surveys, International Series in Operations Research \& Management Science, Vol. 78, Springer, New York, 2005

[6] Khatami Firouzabadi, S.M.A., Henson, B., Barnes, C.: A multiple stakeholders' approach to strategic selection decisions, Computers \& Industrial Engineering, Vol. 54, No. 4, Pergamon Press, Inc., Tarrytown, New York 2008, pp. 851-865

[7] Farahani, R.Z., Steadie Seifi, M., Asgari, N.: Multiple criteria facility location problems: A survey, Applied Mathematical Modelling, Vol. 34, No. 7, 2010, pp. 1689-1709

[8] Sinuany-Stern, Z., Mehrez, A., Tal, A.G., Shemuel, B.: The location of a hospital in a rural region: The case of the Negev, Location Science, Vol. 3, No. 4, 1995, pp. 255-266

[9] Vahidnia, M.H.,Alesheikh, A.A.,Alimohammadi,A.:Hospital site selection using fuzzy AHP and its derivatives, Journal of Environmental Management, Vol. 90, No. 10, 2009, pp. 3048-3056

[10] Chou, T.Y., Hsu, C.L., Chen, M.C.: A fuzzy multi-criteria decision model for international tourist hotels location selection, International Journal of Hospitality Management, Vol. 27, No. 2, 2008, pp. 293-301

[11] Vego, G., Kučar-Dragičević, S., Koprivanac, N.: Application of multi-criteria decision-making on strategic municipal solid waste management in Dalmatia, Croatia Waste Management, Vol. 28, No. 11, 2008, pp. 21922201

[12] Simão, A., Densham, P.J., Haklay, M.: Web-based GIS for collaborative planning and public participation: An application to the strategic planning of wind farm sites, Journal of Environmental Management, Vol. 90, No. 6, 2009, pp. 2027-2040

[13] Al-Shemmeri, T., Al-Kloub, B., Pearman, A.: Computer aided decision support system for water strategic planning in Jordan, European Journal of Operational Research, Vol. 102, No. 3, 1997, pp. 455-472

[14] Hajkowicz, S., Collins, K.: A review of multiple criteria analysis for water resource planning and manage- 
ment, Water Resources Management, Vol. 21, 2007, pp. $1553-1566$

[15] Karleuša, B.: Primjena postupaka višekriterijske optimalizacije u gospodarenju vodama, master thesis, Faculty of Civil Engineering - University of Zagreb, Croatia, 2002

[16] Poletan Jugović, T., Baričević, H., Karleuša, B.: Višekriterijska optimizacija konkurentnosti paneuropskog koridora Vb, Promet - Traffic \& Transportation, Vol. 18, No. 3. 2006, pp. 189-195

[17] Poletan Jugović, T., Jugović, A., Karleuša, B.: Solution Valuating in Transport Planning by Implementation of the Multi-criteria Optimisation, $10^{\text {th }}$ International Conference on Traffic Science ICTS 2006, Transportation and Globalisation, Portorož, Slovenija, December 2006

[18] Saaty, T. L.: The Analytic Hierarchy Process, $2^{\text {nd }}$ edition, RWS Publications, Pittsburgh, 1996

[19] Saaty, T. L.: Fundamentals of Decision Making and Priority Theory, RWS Publications, Pittsburgh, 1994

[20] Vaidya, O.S., Kumar, S.: Analytic hierarchy process: An overview of applications, European Journal of Operational Research, Vol. 169, No. 1, 2006, pp. 1-29

[21] Karleuša, B., Benigar, M., Deluka-Tibljaš, A.: Use of AHP Multi-criteria Optimisation Method for the Optimisation of Garage Facility DOK 3 in Rijeka, $11^{\text {th }}$ International Symposium on Electronics in Traffic ISEP 2003, Ljubljana, October 2003

[22] Yedla, S., Shresthe, R.M.: Multi-criteria, approach for the selection of alternative options for environmentally sustainable transport system in Delhi, Transport research, Vol. 37, No. 8, 2003, pp. 717-729

[23] Frančić, M., Pogarčić, I., Frančić, V.: Requirements Engineering as a Technique for defining Scale pair wise
Comparison in the Application of AHP Method in the planning of Traffic, $17^{\text {th }}$ International Symposium on Electronics in Traffic (ISEP 2009) - Sustainable Transport and Mobility, Ljubljana, March 2009

[24] Pogarčić, I., Frančić, M., Davidović, V.: Application of AHP Method in Traffic Planning, $16^{\text {th }}$ International Symposium on Electronics in Traffic (ISEP 2009) - A Condition for Sustainable Development and Prosperity of A Modern and Safe Transport, Ljubljana, October 2008

[25] www.expertchoice.com, accessed June 2010

[26] Maršanić, R.: Parkiranje u turističkim destinacijama, IQ Plus d.o.o., Kastav, 2008.

[27] Vrščaj, B., Poggio, L., Marsan, F.A.: A method for soil environmental quality evaluation for management and planning in urban areas, Landscape and Urban Planning, Vol. 88, No. 2-4, 2008, pp. 81-94

[28] Ferlin, F.: Rješavanje problema parkiranja u gradu Rovinju u funkciji održivog razvoja prometnog sustava grada, master-thesis, Faculty of Civil Engineering - University of Rijeka, Rijeka, 2008

[29] Zakon o zaštiti okoliša, Narodne novine, No. 110, 2007

[30] Uredba o procjeni utjecaja zahvata na okoliš, Narodne novine, No. 64, 2008 and No. 67, 2009

[31] Marinos, V., Marinos, P., Hoek, E.: The geological strength index: applications and limitations, Bulletin of Engineering Geology and the Environment, Vol. 64, No.1, 2005, pp. 55-65

[32] Bieniawski, Z. T.: Engineering Rock Mass Classifications: A Complete Manual for Engineers and Geologists in Mining, Civil and Petroleum Engineering, John Wiley \& Sons, New York-Chichester-Brisbane-TorontoSingapore,1989 